American Journal of Pharmaceutical Education 2020; 84 (5) Article 7910.

\title{
COMMENTARY
}

\section{Facilitating Advancement of Clinical-Track Pharmacy Faculty Members}

\author{
William Allan Prescott Jr., PharmD ${ }^{\mathrm{a}, \mathrm{b}}$ \\ ${ }^{a}$ University at Buffalo, School of Pharmacy and Pharmaceutical Sciences, Buffalo, New York \\ ${ }^{\mathrm{b}}$ Editorial Board Member, American Journal of Pharmaceutical Education, Arlington, Virginia \\ Submitted June 11, 2019; accepted October 31, 2019; published May 2020.
}

\begin{abstract}
Clinical faculty members in most pharmacy practice departments are expected to engage in practice, teaching, research and scholarship, and service. Although new clinical faculty members are typically well equipped to engage in the clinical practice aspect of their position, they generally lack experience in the other academic pillars and, depending on the institution, may not have dedicated time to engage in each area of effort, particularly research and scholarship. Consequently, achieving balance and realizing success in the tripartite mission of academia can be challenging. A multimodal approach can be used to facilitate advancement among clinical faculty members through faculty development and mentoring, attention to workload, clear expectations, and provision of feedback on performance and progression toward goals. This approach, which has been well received, has been associated with higher rates of promotion among clinical faculty members at one institution. Schools and colleges of pharmacy that value research and scholarship and are struggling to facilitate advancement among clinical faculty members may consider adopting some or all aspects of this program.
\end{abstract}

Keywords: pharmacy, faculty development, mentoring, workload, promotion, clinical faculty non-tenure track faculty

The proportion of nontenure-track faculty members in schools and colleges of pharmacy, most of whom are "clinical faculty" in pharmacy practice, has dramatically increased over the past three decades. Since AACP began tracking first-time faculty member data in 2013-2014, the ratio of nontenure- to tenure-track faculty members entering academia has averaged just above two to one, and in 2019-2020, more than half of all faculty members were nontenure-track or employed at nontenure institutions. ${ }^{1}$ The vast majority of clinical faculty members engage in clinical practice, teaching, research and scholarship, and school or department service, albeit to different extents based on the values and priorities of a given school or college. $^{2}$ While the opportunity to engage in diverse activities is attractive to new faculty members, ${ }^{3}$ balancing these pillars and having success in each of them without burning out can be challenging, particularly among new faculty members. ${ }^{4}$ Although there are many factors that can influence productivity and the rate of advancement, developing faculty members and providing them with protected time is vital.

Corresponding Author: William Allan Prescott, Jr., University at Buffalo School of Pharmacy and Pharmaceutical Sciences, 218 Pharmacy Building, Buffalo, NY 14214. Tel: 716-645-4780. Fax: 716-829-6093. Email:

prescott@buffalo.edu.
Qualifications for clinical faculty positions vary by school and by the nature of the position. More than onequarter of new pharmacy practice faculty members enter academia immediately after completing a postgraduate year one residency, just under one-third do so after completing either a postgraduate year two residency or fellowship, and $40 \%$ do so after gaining experience in clinical practice (either immediately following graduation or after residency training). ${ }^{3}$ Although residency training can include aspects of teaching and research and scholarship, its focus is on the development of clinical pharmacists responsible for the provision of patient care. Similarly, although fellowship training can include aspects of teaching and patient care, its focus is research and scholarship. In a survey of first-time faculty members, less than two-thirds reported having experience precepting pharmacy students, facilitating small-group discussions, or serving as a guest-lecturer at a pharmacy school, and only $40 \%$ indicated they had published a peerreviewed article prior to being hired. ${ }^{3}$ When considering the tripartite mission of academia (ie, teaching, service, and research and scholarship), many new clinical faculty members may be well equipped to engage in one aspect of academia, but generally lack adequate experience in the other academic pillars. This mismatch between training and expectations can affect the ability of a new faculty member to realize success, which can lead to burnout, job 


\section{American Journal of Pharmaceutical Education 2020; 84 (5) Article 7910.}

dissatisfaction, and attrition., ${ }^{4,5}$ Therefore, effective onboarding and orientation of new faculty members and intentional faculty development and mentoring are of utmost importance. ${ }^{4-10}$ Two surveys, one published in 2004 and the other in 2013 , estimated that $75 \%$ and $91 \%$ of pharmacy schools offered a formal orientation process and faculty mentoring program, respectively.,11

Equally important is providing faculty members with the time to be effective in each academic pillar. Faculty members, in both pharmacy and other health sciences, are often expected to place an emphasis on scholarly activities while maintaining their teaching and service responsibilities. ${ }^{12}$ In comparison to tenured and tenure-track faculty members who may dedicate half to three-quarters of their time to research, clinical faculty members are often expected to distribute their effort more evenly across the academic pillars. This can result in a considerable workload and a sense of being "spread thin," which is a deterrent to retention of pharmacy faculty. ${ }^{5}$ Anecdotal evidence suggests that when workload issues arise, many clinical faculty members focus their efforts on tasks that are important and urgent (such as clinical practice, teaching, and service), and place activities that are important but not urgent (such as research and scholarship) on the back burner. This is especially concerning in pharmacy schools that value research and scholarship and expect productivity in this pillar in order for a faculty member to be promoted and/or granted tenure, as is the case at our institution. In a survey of pharmacy practice faculty members with clinical responsibilities, insufficient time was identified as the most common barrier to engaging in research and scholarship. ${ }^{13}$ Therefore, assessing workload and establishing a realistic balance of duties and performance expectations across all academic pillars to promote productivity in research and scholarship is recommended. ${ }^{14,15}$

At our institution, we have implemented a multimodal approach to promote faculty success across the pillars of academia (Table 1). As is the case across much of the Academy, our clinical faculty members have historically struggled to engage in research and scholarship. As recommended by Bosso and colleagues, incorporation of a clinical faculty model that is conducive to research and scholarship should be seriously considered. ${ }^{15}$ Therefore, although attention was given to all facets of academia, the driving force behind this initiative was to improve faculty advancement through mentoring and development in research and scholarship, increase protected time for clinical faculty members to engage in research and scholarship, improve transparency of expectations, and enhance feedback on performance and progression toward shared goals.
As a first step, in 2013 we established a new faculty onboarding and orientation process, developed a faculty mentoring program, and launched a monthly faculty development series. All aspects of this program are driven by the department chair and overseen by our department's Faculty Development and Mentoring Committee. The onboarding process begins prior to the new faculty member's start date and includes a 24-session orientation during their first month of employment. The orientation, which is provided by faculty members, staff members, and school administrators, not only serves to provide guidance about the institution and how to be successful in the tripartite mission, but also gives new faculty members the opportunity to interact with their supervisor and new colleagues to help them establish relationships within the school. The mentoring program, which begins immediately after completing the orientation-phase, is designed to develop the new faculty member in all areas of academia, promote balance, and create win-wins for the mentor and mentee (eg research and scholarship collaborations). This program includes both a formal and informal component for new and existing faculty members, respectively. New faculty members at the assistant professor rank are required to enroll in the formal mentoring program, which was individualized based on track (ie, a different set of standards were developed for clinical and tenure-track faculty members). In the case of clinical faculty members, new faculty members are paired with one or two senior-rank clinical faculty members: the mentor-mentee match is a joint decision between the mentor, mentee, and department chair. Although a set of deliverables is provided to guide the process (Table 1), mentors are given the autonomy to mentor as they see fit. Formal mentoring lasts three years, after which the program takes on a more informal structure. Faculty development occurs alongside mentoring. All faculty members, regardless of rank and track, are strongly encouraged to attend monthly faculty development sessions. Since inception, more than 50 active-learning and discussion-based sessions have been offered across all aspects of academia: $30 \%$ on education and teaching, $30 \%$ on research and scholarship, $25 \%$ on personal and professional development, and $15 \%$ on service. Materials from all sessions are housed in an electronic library on Blackboard (Blackboard Inc., Washington, DC) for future reference. Each of the aforementioned aspects (onboarding/orientation, mentoring, and faculty development) are evaluated through faculty surveys for the purposes of quality improvement and accreditation reporting.

Understanding that mentoring and faculty development efforts are futile if faculty members are not given the time they need to engage in the academic pillars, in 2013, 
American Journal of Pharmaceutical Education 2020; 84 (5) Article 7910.

Table 1. A Multimodal Approach to Facilitating Advancement Among Clinical-Track Pharmacy Faculty

\begin{tabular}{|c|c|c|}
\hline Component & Responsibility & Description \\
\hline New Faculty Onboarding & $\begin{array}{l}\text { Department Chair } \\
\text { Clinical Faculty } \\
\text { T/TT Faculty } \\
\text { Department Staff }\end{array}$ & $\begin{array}{l}\text { Sessions provide orientation to HR; the } \\
\text { community; organizational structure; } \\
\text { policies/procedures; curriculum and } \\
\text { assessment; expectations pertaining to } \\
\text { clinical practice, teaching, service, and } \\
\text { research/scholarship; promotion/tenure; time } \\
\text { management, prioritization, and goal setting; } \\
\text { and miscellaneous items (eg, email, calendar) }\end{array}$ \\
\hline Faculty Mentoring & $\begin{array}{l}\text { Department Chair } \\
\text { Clinical Faculty } \\
\text { T/TT Faculty } \\
\text { FDMC }\end{array}$ & $\begin{array}{l}\text { Deliverables (based on established timelines) } \\
\text { include, but are not limited to: setting goals; } \\
\text { develop research focus/foci; establish a } \\
\text { clinical practice and EE training site; design/ } \\
\text { deliver teaching and assessment items under } \\
\text { mentor oversight; develop an elective course; } \\
\text { serve on a school committee in year } 2 \text { and co- } \\
\text { chair a school/department committee in year } \\
3 \text {; publish }>1 \text { collaborative review article/ } \\
\text { case report per year in years } 1-3 \text { and }>1 \\
\text { original research abstract/manuscript per year } \\
\text { in years } 2 \text { and } 3 \text {; and provide at least two } \\
\text { peer-reviews for scientific journals annually. }\end{array}$ \\
\hline Faculty Development & $\begin{array}{l}\text { Department Chair } \\
\text { Clinical Faculty } \\
\text { T/TT Faculty } \\
\text { FDMC }\end{array}$ & $\begin{array}{l}\text { Topics: education/teaching skills (eg, active- } \\
\text { learning, exam writing skills, course } \\
\text { assessment); service (eg, student advising, } \\
\text { professional organization involvement); } \\
\text { research/scholarship (eg, abstract/manuscript } \\
\text { writing, grantsmanship, biostatistics); and } \\
\text { personal/professional development (eg, } \\
\text { faculty citizenship, work-life balance, } \\
\text { burnout, and promotion/tenure and } \\
\text { constructing the dossier). }\end{array}$ \\
\hline Workload Analysis & $\begin{array}{l}\text { Department Chair } \\
\text { Department Staff }\end{array}$ & $\begin{array}{l}\text { Teaching, service and research/scholarship } \\
\text { metrics are tracked annually and incorporated } \\
\text { into Faculty Performance Reviews. Provides } \\
\text { data pertaining to DOE that facilitates } \\
\text { workload distribution/redistribution to } \\
\text { achieve target DOE. }\end{array}$ \\
\hline Faculty Performance Review & $\begin{array}{l}\text { Department Chair } \\
\text { Clinical Faculty } \\
\text { T/TT Faculty }\end{array}$ & $\begin{array}{l}\text { Includes an annual self-assessment of goals, } \\
\text { peer-review, and department chair review. } \\
\text { Department chair review provides an } \\
\text { overview of the faculty's DOE (vs. expected/ } \\
\text { average); metrics pertaining to teaching, } \\
\text { service, and research/scholarship (vs. } \\
\text { expected/average); subjective assessment of } \\
\text { faculty citizenship; and, assessment of } \\
\text { performance/progression toward promotion. }\end{array}$ \\
\hline
\end{tabular}

Abbreviations: $\mathrm{T}=$ tenured, $\mathrm{TT}=$ tenure track, $\mathrm{FDMC}=$ Faculty Development and Mentoring Committee, $\mathrm{HR}=$ human resources,

$\mathrm{EE}=$ Experiential Education, IPPE $=$ introductory pharmacy practice experience, $\mathrm{APPE}=$ advanced pharmacy practice experience,

$\mathrm{DOE}=$ distribution of effort 


\section{American Journal of Pharmaceutical Education 2020; 84 (5) Article 7910.}

our second step was the development of a mathematical model to determine faculty workload. The model, which assigned a time-value to faculty activities in the areas of clinical practice, teaching, and service was developed by the department chair in cooperation with clinical faculty members, tenured/tenure-track faculty members, and school administrators, with each type of practice site (inpatient, outpatient, consulting, etc) and faculty rank represented. This model provided data that were used to determine distribution and redistribution of workload and restructuring of clinical service coverage, curricular responsibilities, and service duties to mitigate faculty burnout and to encourage success of our faculty in each academic pillar, particularly in research and scholarship. The following are three examples: inpatient clinical faculty members were paired off and placed on a shared clinical service to facilitate protected time away from their practice site; course coordination workload was redistributed to ensure a maximum of one required or core course per semester and one high-workload course per year; and committee and student advising workload was redistributed in a more equitable manner. Our leadership holds the opinion that if faculty members are expected to engage in research and scholarship, then at least $10 \%$ to $20 \%$ of their time should be allotted to this area. At our institution, we have been able to better balance the distribution of effort among clinical faculty members to approximate $30 \%$ teaching, $30 \%$ clinical practice, $20 \%$ research/scholarship, and 20\% service. In 2018, AACP faculty survey data reported a $7 \%$ increase in the number of faculty members agreeing that the amount of time they spent on research was appropriate.

The third step, implemented in 2017, was modification of the annual faculty performance review process. This was done to better communicate expectations, compare and contrast distribution of effort in relation to departmental averages and targets, and compare and contrast performance metrics with departmental and national data. Because faculty citizenship was identified as a priority by the faculty, a qualitative assessment of faculty engagement and collegiality was incorporated. Lastly, progress toward promotion and/or tenure was included in the assessment.

Each aspect of our program has been well received, and overall, our school has seen a dramatic uptick in research and scholarly productivity and advancement among our clinical faculty members. Since the launch of this initiative, the mean number of manuscripts per clinical faculty member per year has nearly doubled, from 0.9 in 2012 to 1.7 in 2018; approximately threefold higher than the national average among public institutions. ${ }^{16}$ Because low rates of research and scholarship had been the predominant barrier to promotion among clinical faculty members, not surprisingly, we have seen a considerable increase in successful promotions among both new and established faculty members. Although there is no set timeline for promotion in the clinical ranks at our school, general recommendations are for junior faculty members to pursue promotion during appointment year 6 . Between 2002 and 2012, the 10 years preceding this initiative, three clinical faculty were promoted, all to the rank of clinical associate professor. Since the launch of this initiative, threefold as many faculty members have been promoted: eight were promoted to the rank of clinical associate professor and one to the rank of clinical professor. As a result, the proportion of senior-rank clinical faculty members in our department has increased from $25 \%$ in 2013 to $48 \%$ in 2019 , increasing our capacity to mentor and develop junior faculty members. Our faculty members have also been promoted in a timelier manner: the median time for promotion to the associate rank among new faculty members who directly entered this program upon hire was six years. This is one-half the median time among faculty members who were hired prior to establishment of the program. Three junior faculty members who were hired before implementation of this program continue to work toward promotion (median years at rank $=16$ years).

There is often a reciprocal relationship between faculty members and the organization that employs them. As suggested by Conklin and colleagues, faculty members develop a sense of commitment to the school or college only after the organization has made a commitment to them. ${ }^{5}$ We have outlined a multimodal approach to express organization commitment and to facilitate advancement among clinical track faculty members through faculty development and mentoring, attention to faculty workload, setting of clear expectations, and provision of formal feedback on progress toward goals. At our institution, this approach has been associated with higher rates of advancement among our clinical faculty members. Schools and colleges of pharmacy that value research and scholarship and are struggling to facilitate advancement among clinical faculty members may consider adopting some or all of the aspects of this program.

\section{REFERENCES}

1. American Association of Colleges of Pharmacy. Pharmacy Faculty Demographics and Salaries Reports. https:/www.aacp.org/ research/institutional-research/pharmacy-faculty-demographics-andsalaries. Accessed May 16, 2020.

2. Glover ML, Armayor GM. Expectations and orientation activities of first-year pharmacy practice faculty. Am J Pharm Educ.

2004;68(4):Article 87.

3. Wanat MA, Fleming ML, Fernandez JM, Garey KW. Education, training, and academic experience of newly hired, first-time 


\section{American Journal of Pharmaceutical Education 2020; 84 (5) Article 7910.}

pharmacy faculty members. Am J Pharm Educ. 2014;78(5):Article 92.

4. El-Ibiary SY, Yam L, Lee KC. Assessment of burnout and associated risk factors among pharmacy practice faculty in the United States. Am J Pharm Educ. 2017;81(4):Article 75.

5. Conklin MH, Desselle SP. Job turnover intentions among pharmacy faculty. Am J Pharm Educ. 2007;71(4):Article 62. 6. Fuller K, Maniscalco-Feichtl M, Droege M. The role of the mentor in retaining junior pharmacy faculty members. Am J Pharm Educ. 2008;72(2):Article 41

7. Boyce EG, Burkiewicz JS, Haase MR, et al. Clinical faculty development. Pharmacotherapy. 2009;29(1):124-126.

8. Guglielmo BJ, Edwards DJ, Franks AS, et al. A critical appraisal of and recommendations for faculty development. Am J Pharm Educ. 2011;75(6): Article 122.

9. Wanat MA, Garey KW. A blueprint for transitioning pharmacy residents into successful clinical faculty members in colleges and schools of pharmacy. Am J Pharm Educ. 2013;77(9):Article 200. 10. Baker B, DiPiro JT. Evaluation of a structured onboarding process and tool for faculty members in a school of pharmacy. Am J Pharm Educ. 2019;83(6):Article 7100.
11. Metzger AH, Hardy YM, Jarvis C, et al. Essential elements for a pharmacy practice mentoring program. Am J Pharm Educ. 2013;77(2):Article 23.

12. Smesny AL, Williams JS, Brazeau GA, et al. Barriers to scholarship in dentistry, medicine, nursing, and pharmacy practice faculty. Am J Pharm Educ. 2007;71(5):Article 91.

13. Robles JR, Youmans SL, Byrd DC, Polk RE. Perceived barriers to scholarship and research among pharmacy practice faculty: survey report from the AACP scholarship/research faculty development task force. Am J Pharm Educ. 2009;73(1):Article 17.

14. Fitzpatrick LR, Millette-Snodgrass C, Atef E. A novel mathematical model for determining faculty workload. Am J Pharm Educ. 2016;80(9):Article 152.

15. Bosso JA, Hastings JK, Speedie MK, Rodriguez de Bittner M. Recommendations for the successful pursuit of scholarship by pharmacy practice faculty members. Am J Pharm Educ. 2015;79(1):Article 4.

16. Chisholm-Burns MA, Spivey C, Martin JR, Wyles C, Ehrman C, Schlesselman LS. A 5-year analysis of peer-reviewed journal article publications of pharmacy practice faculty members. Am J Pharm Educ. 2012;76(7):Article 127. 